\title{
THE INFLUENCE OF GENDER AND BRUXISM ON THE HUMAN MAXIMUM BITE FORCE
}

\author{
AVALIAÇÃO DA INFLUÊNCIA DO GÊNERO E DO BRUXISMO \\ NA FORÇA MÁXIMA DE MORDIDA
}

Patrícia dos Santos CALDERON ${ }^{1}$, Evelyn Mikaela KOGAWA¹, José Roberto Pereira LAURIS², Paulo César Rodrigues CONTI ${ }^{3}$

1- Graduate student, Department of Prosthodontics, Bauru Dental School, Bauru, São Paulo, Brazil.

2- Assistant Professor, Department of Public Health, Bauru Dental School, Bauru, São Paulo, Brazil.

3- Full Professor, Department of Prosthodontics, Bauru Dental School, Bauru, São Paulo, Brazil.

Corresponding address: Prof. Dr. Paulo César Rodrigues Conti - Faculdade de Odontologia de Bauru- USP- Departamento de Prótese

Alameda Doutor Octávio Pinheiro Brisolla, 9-75- CEP: 17012-901 - CP 73 - Bauru- SP- Brazil - Phone/Fax: (+55) 14 - 3235-8340

e-mail: pcconti@fob.usp.br

Received: September 11, 2006 - Modification: October 20, 2006 - Accepted: October 24, 2006

\begin{abstract}
$T_{\text {t }}$

he objective of this research was to evaluate the influence of gender and bruxism on the maximum bite force. The concordance for the physical examination of bruxism between examiners was also evaluated. One hundred and eighteen individuals, from both genders, bruxists and non-bruxists, with an average age of 24 years, were selected for this purpose. For group establishment, every individual was submitted to a specific physical examination for bruxism (performed by three different examiners). Subjects were then divided into four groups according to gender and the presence of bruxism. The maximum bite force was measured using a gnathodynamometer at the first molar area, three times on each side, performed twice. The two measurements were made with a 10-day interval. The highest value was recorded. The mean maximum bite force was statistically higher for males $(587.2 \mathrm{~N})$ when compared to females $(424.9 \mathrm{~N})(\mathrm{p}<0.05)$, regardless of the presence of bruxism. The presence of bruxism did not influence the bite force (mean maximum bite force value for bruxists: $490.1 \mathrm{~N}$, and for non bruxists: $522.1 \mathrm{~N})(\mathrm{p}>0.05)$. The concordance between examiners for physical examination of bruxism was considered optimal.

Uniterms: Bite force; Gender; Bruxism.
\end{abstract}

\footnotetext{
RESUMO

Q

objetivo dessa pesquisa foi avaliar a influência do gênero e do bruxismo na força máxima de mordida. A concordância interexaminadores para o exame físico de bruxismo também foi avaliada. Cento e dezoito voluntários, com idade média de 24 anos, divididos por gênero e pela presença de bruxismo, foram selecionados. Para o estabelecimento da amostra todos os voluntários foram submetidos a um exame físico específico para bruxismo (realizado por três examinadores). Então, os voluntários foram divididos em quarto grupos de acordo com o gênero e a presença de bruxismo. A força máxima de mordida foi mensurada, com o auxílio de um gnatodinamômetro, na região de primeiro molar, três vezes de cada lado, em duas sessões distintas. As sessões foram separadas por um intervalo de 10 dias. O maior valor dentre os doze obtidos, foi utilizado como sendo a força máxima. A força máxima de mordida foi estatisticamente maior para o gênero masculino (587.2 N) quando comparado com o gênero feminino $(424.9 \mathrm{~N})(\mathrm{p}<0.05)$, independentemente da presença de bruxismo. A presença de bruxismo não demonstrou influência na força máxima de mordida (média da força máxima de mordida para bruxômanos = 490.1 N, e para não bruxômanos = $522.1 \mathrm{~N})(\mathrm{p}>0.05)$. A concordância entre os examinadores para o exame físico de bruxismo foi considerada favorável. Unitermos: Força de mordida; Gênero; Bruxismo.
} 


\section{INTRODUCTION}

Bite force is the result of the coordination between different components of the masticatory system (muscles, bones and teeth). Its determination has been considered important in the diagnosis of disturbances of the stomatognathic system ${ }^{1}$.

According to Hatch, et al. ${ }^{2}$, in 2000, the bite force and the number of occluding teeth are determinant factors in the chewing performance. Maximum bite force is understood as the capacity of the mandibular elevator muscles to perform a maximum strain of mandibular teeth against the maxillary teeth, under favorable conditions ${ }^{1}$.

Mandibular muscle action determines the amount of existing force to triturate the food, and several methods are used to measure $\mathrm{it}^{3}$. Gnathodynamometers and force transducers are some of methods for the evaluation of bite force ${ }^{4}$.

When prevalence of bruxism is considered, different figures are found. Either epidemiologic survey studies, carried out on student populations ${ }^{5}$, or those conducted in general populations ${ }^{6}$ report from $6 \%$ to $20 \%$ of adults with clenching or grinding. Regarding the gender, clenching seems to be $22 \%$ more frequent in females, even though this tendency has not been verified when grinding the teeth is considered $^{7}$. The possible relationship between bite force and bruxism is unclear. It has also been suggested that gender plays an important role in the maximum bite force $e^{2,8}$. Based on that, the aim of this study is to determine the influence of gender and bruxism on the maximum bite force.

\section{MATERIALAND METHODS}

\section{Sample selection}

This research was approved by the Committee on Ethics in Research (CEP) of Bauru Dental School, University of São Paulo (Process \# 146/2002).

The subject's recruitment was done among Bauru Dental School employees, dental and graduate students, as well as patients seeking for regular dental treatment at school.

Initially, all individuals were submitted to an initial anamnesis (personal profile, general questions about systemic diseases, as well as a questionnaire about parafunctional habits) and an intraoral physical examination, all performed by the same examiner.
The Temporomandibular Disorders (TMD) questionnaire below was applied to detect the presence of TMD symptoms, one of the exclusion criteria for the present study.

1. Do you have difficulties to open the mouth?

2. Do you have difficulties in mandibular side movements?

3. Do you feel discomfort or muscle pain when chewing?

4. Do you frequently feel headaches?

5. Do you feel neck and/or shoulder pain?

6. Do you feel pain on the ear or near to it?

7. Do you hear any temporomandibular joint noise?

8. Do you feel your bite "abnormal”?

9. Do you use only one side of your mouth to chew?

10. Do you feel face pain when awakening?

Each question had three answer options: YES, NO and SOMETIMES. Each YES received score 2, each SOMETIMES received score 1 and each NO received score 0 . Questions 6 and 7 received score 3 for each YES corresponding to bilateral symptoms and score 2 for unilateral symptoms. Question 4 receives score 3 when frequent and intense pain is reported ${ }^{9}$.

The sum of the obtained scores allowed sample classification in non TMD (from 0 to 3 ), mild TMD (from 4 to 8), moderate TMD (from 9 to 14) and severe TMD (from 15 to 23).

After this initial procedure, applied to the entire sample, the following exclusion criteria, based on the Lavigne, Rompré and Montplaisir ${ }^{10}$ recommendations, were applied to all participants:

1. More than two missing posterior teeth (excluding third molars);

2. Presence of removable dentures;

3. Presence of gross malocclusion, specifically: anterior open bite, unilateral cross bite, overjet higher than $6 \mathrm{~mm}$, closing arc interference that results in a difference from centric relation to maximum intercuspation higher than 5 mm (TMD development occlusion risk factors, according to Pullinger, Seligman and Gornbein ${ }^{11}$.

4. Presence of major neurological, psychiatric or motor disorders ${ }^{12,13}$.

5. Values higher than score 8 in TMD questionnaire.

\section{Group's establishment}

After that, a specific questionnaire (Figure 1), suggested by Molina, et al. ${ }^{14}$, in 1999, and a specific physical examination, performed by three previously calibrated

\section{FIGURE 1- Bruxism questionnaire}

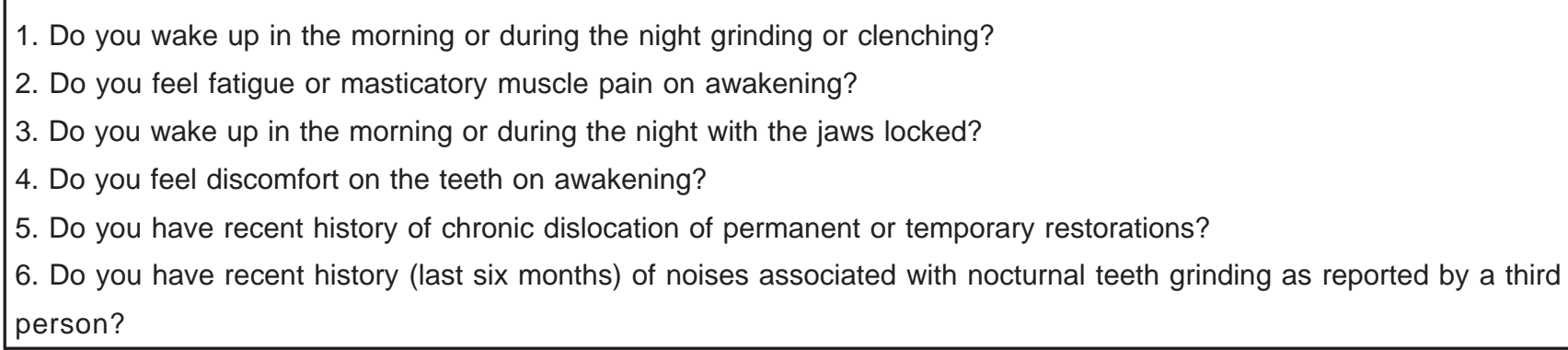


graduated students, were performed in order to determine the presence of bruxism. Both the questionnaire and physical examination were performed on the same day by the 3 examiners, blind to the results and to the subject's TMD condition.

The physical examination ${ }^{10}$ included analysis of coincident tooth wear, shiny spots on restorations, masseter muscle hypertrophy upon digital palpation (scored positive if the examiner detected muscle volume approximately tripled upon a voluntary clench in maximum intercuspation position).

Each participant was examined by the three examiners in order to have the examination process concluded, and the final diagnosis, bruxist or non-bruxist, had to be in agreement by the majority of examiners.

After this process, and divided according to gender and presence of bruxism, 118 individuals were selected, with age between 18 and 44 years old, with the presence of all first molars, and TMD score below 8. All individuals were properly informed about the research goal and objectives, as well as about the procedures to be conducted, by an information letter.

After that, the entire sample was informed about the purpose of the research and after being aware of the procedures to be performed, they signed a free and informed consent term, in accordance with resolution 196/96 of the National Health Council.

\section{Bite force measurement}

Bite force was measured by a digital dynamometer (model IDDK, serial number 3222, Kratos Equipamentos Industriais Ltda, Cotia, São Paulo, Brazil) adapted for oral conditions (Figure 2). This appliance, an instrument for measuring force, uses electronic technology and comprises a bite fork and digital body. Its high precision load cell and its electronic circuit for indicating force provide precise measurements that are easy to read from its digital three-digit liquid crystal dial $^{1}$.

The appliance presents a scale in kgf or $\mathrm{N}$, selector switch for the traction or compression functions, a button for 'set zero' and a selector switch for the 'peak' option. The 'set zero' allows the values obtained to be accurately controlled. The position 'peak' records and saves the greatest force applied during the test.

Before recording the bite force, the individuals were seated in upright position and previously trained to perform

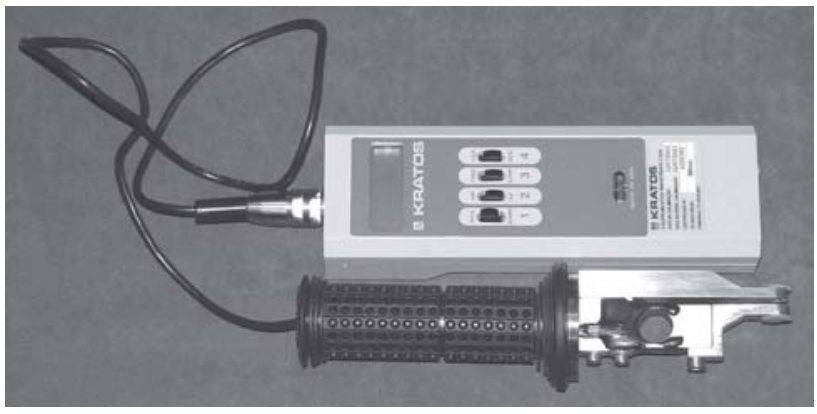

FIGURE2 their strongest bite over the device.

The gnathodynamometer bite fork was covered with a latex finger cot to protect the individuals against contamination ${ }^{1}$.

The measurements were performed on the first molar region (Figure 3).

Two records were performed, with an average interval of ten days. In each record, 6 measurements were performed, 3 on each side, adding up to 12 measurements for each individual. The higher value found over those 12 measurements was recorded as the maximum bite force for that individual ${ }^{3,8,15,16}$.

The same examiner performed all measurement processes to the entire sample.

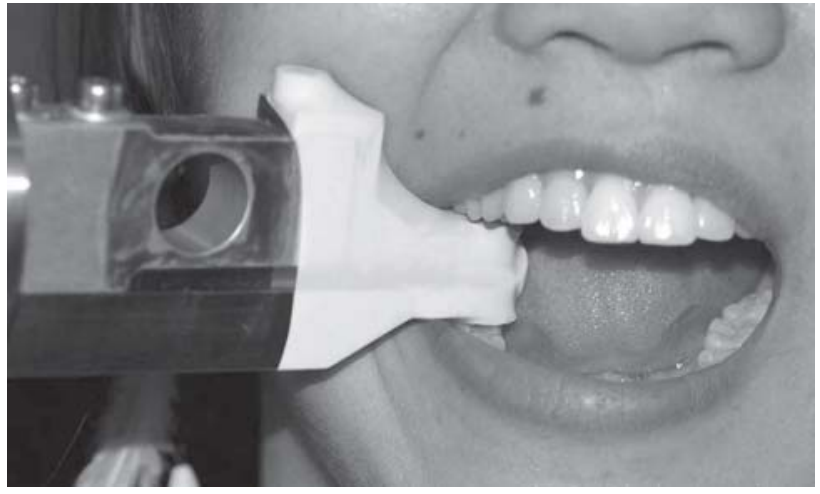

FIGURE3

\section{Statistics}

The two-way ANOVA, with a significance level of 5\% accounted for statistical analysis. Post-hoc tests were performed, if necessary.

Kappa test was used to determine concordance between examiners for the bruxism physical examination, following parameters recommended by Landis and Koch ${ }^{17}$.

\section{RESULTS}

The distribution of mean age for the whole sample is shown in Table 1.

The mean values of maximum bite force, by group and gender, and respective standard deviations, are shown on Table 2.

The highest bite force value in the female non-bruxist group was $834.6 \mathrm{~N}$, and lowest value was $165.7 \mathrm{~N}$. For the male non-bruxist group, such values were, respectively, 893.4 $\mathrm{N}$ and $337.4 \mathrm{~N}$. For the female bruxist group, the highest maximum bite force value was $656.1 \mathrm{~N}$, whereas the lowest value was $108.9 \mathrm{~N}$ (this was the lowest value obtained in this research). For the male bruxist group, the highest value was 999.3 $\mathrm{N}$ (this was the highest value obtained on this research), and the lowest value for this group was $262.8 \mathrm{~N}$.

A significant difference between the genders $(p<0.05)$ was found. The presence of bruxism, however, did not influence bite force values ( $p>0.05)$. Right and left sides 
also presented similar values ( $\mathrm{p}>0.05)$.

The Kappa values for intra-examiner concordance for the clinical examination of bruxism can be seen in Table 3 .

\section{DISCUSSION}

There are many studies on the influence of gender or bruxism on the maximum bite force $\mathrm{e}^{2,8,15,16,18-23}$. Most of these studies, however, differ with regard to the diagnostic procedures and methodologies. Therefore, caution is recommended when comparing the different bite force measurements.

In the present study, a mean maximum bite force in the female groups ranges from 108.9 to $834.6 \mathrm{~N}$ (mean of 424.2), and a mean maximum bite force in the male groups ranges from 262.8 to $999.3 \mathrm{~N}$ (mean of 587.2), which agrees with previous studies ${ }^{15,19,21,23}$.

No significant difference was found between the right and left sides in any of the groups assessed, in agreement with previous findings ${ }^{20}$.

The hypothesis that bruxism is capable to change the bite force by muscle strengthening is still unproved. If the bite force was truly influenced by bruxism, its measurement could be an important feature in the diagnosis of such habit ${ }^{1}$.

One of the most controversial factors when recording bite force is mouth opening, caused by the dynamometer bite fork thickness. Fields, et al. ${ }^{24}$, in 1986, found approximately $20 \mathrm{~mm}$ as the ideal mouth opening, when the first molar is used, close to that used in the present study

TABLE 1- Mean of age (years) in each group

\begin{tabular}{lll}
\hline \multicolumn{1}{l}{ Gender } & Female & Male \\
Group & & \\
\hline Non bruxist & 22 & 25 \\
Bruxist & 23 & 26 \\
\hline
\end{tabular}

TABLE 2- Maximum bite force for groups and genders (in $\mathrm{N})$, and respective standard deviations

\begin{tabular}{lcc}
\hline \multicolumn{1}{c}{ Gender } & Female & Male \\
\hline Non bruxist & $454.3(125.3)$ & $590.0(145.8)$ \\
Bruxist & $395.6(138.5)$ & $584.5(185.6)$ \\
\hline
\end{tabular}

(18mm).

Several studies ${ }^{2,8}$ found higher maximum bite force values for males, in agreement with the present study. This fact, however, was not the conclusion of other papers $8,15,16,20,21,23$.

Differences in bite force between males and females, however, are not found when children are considered ${ }^{16}$. This is probably because body structure and muscle strength are very similar in such population.

Waltimo and Kononen ${ }^{8}$, in 1993, reported significant differences on the maximum bite force between genders only for the molar region, which can probably be explained by the fact that the bite force on the incisal area could be limited by the periodontal ligament sensitivity and not by the muscle strength, as in the posterior area of the mouth. Raadsheer, et al. ${ }^{23}$ also could not find differences between genders when measuring bite force between canines.

The non-difference between male and female bite force values reported in some studies on adults can be due to the reduced sample size ${ }^{16}$, or unbalanced gender distribution ${ }^{15,20}$.

Masticatory habits of the population and not only body dimensions can influence the bite force ${ }^{15}$, which can also explain the similarity between genders in some studies.

Some authors ${ }^{2,8}$ stated thats male present higher maximum bite force due to higher muscle strength, while Bakke, et al. ${ }^{25}$, found positive correlation between the thickness of masseter muscle and the bite force.

Seven years later, in 1999, Raadsheer, et al. ${ }^{23}$ evaluated the contribution of masseter, temporal and anterior belly of the digastric muscles thickness to human bite force magnitude, and found that the masseter thickness showed significant correlation with the bite force magnitude.

In this research, as observed by others ${ }^{19,22}$, when association between maximum bite force and bruxism were studied, no significant differences were found, regardless of gender. Different results, however, have also been previously reported ${ }^{3,19}$.

It has been reported that individuals with sleep bruxism can present clinical signs, like tooth wear, periodontal diseases and $\mathrm{TMD}^{26,27}$ due to the efforts resulting of these habits.

Nunes $^{28}$, conducted a research on the association between sleep bruxism and TMD, and found that TMD individuals are more likely to have pain after bruxism than the control group individuals (asymptomatic bruxists), which could indicate two possibilities: asymptomatic bruxists could be more resistant to fatigue and pain than the experimental group individuals, or a pre-existent TMD process would be required to trigger the pain in bruxists.

According to the author ${ }^{28}$, for some patients, the pain

TABLE 3- Kappa values between examiners, for the bruxism diagnosis

\begin{tabular}{lccc} 
Examiners & Kappa value & Similar diagnosis $(\mathbf{n})$ & Similar diagnosis (\%) \\
\hline 1 and 2 & 0.77 & 105 & 88.33 \\
1 and 3 & 0.64 & 99 & 81.67 \\
2 and 3 & 0.62 & 99 & 81.67 \\
\hline
\end{tabular}


plays a modulator role in parafunctional activity, decreasing the EMG activity of masticatory muscles.

For the asymptomatic group, on the other hand, the habit (bruxism) would cause dental wear and/or muscle hypertrophy.

Since the individuals with moderate and severe TMD were excluded from the sample, it could be expected that individuals from the bruxism group presented a hypertrophic muscle and some degree of dental wear (both factors considered on the bruxism physical exam and part of the inclusion criteria for this group).

Significant differences of all polysomnographic variables were reported by Del Fabbro ${ }^{29}$, who monitored a bruxist patient during 30 consecutive nights of sleep, which highlighted the high variability of bruxism activity and intensity for the same subject.

Thus, bite force measurement performed in the active bruxism period could be influenced by post-exercise muscle fatigue, leading to decreased values. As observed by Lavigne, Rompré e Montplaisir ${ }^{10}$, in 1996, symptomatic bruxists performed less motor activity due to the symptomatology. It could cause a reduced bite force capacity.

On the other hand, some studies ${ }^{21,22}$ suggested that the jaw-closing muscles of bruxists might have benefited from a "training effect" as a result of all this activity, resulting in muscles that are stronger and possibly more resistant to fatigue.

Helkimo e Ingervall ${ }^{19}$ also found that individuals with clenching and grinding habits were found to have higher bite force only on the incisors, but not on the molars. This happens because the habits are normally performed in noncentric positions, when the required muscles of these positions are exercised (which happens when bite force in the anterior regions are measured), and not in a centric position (which happens when the posterior regions are measured).

Gibbs, et al. ${ }^{18}$ found higher bite force values on the posterior region for bruxists than for the control group. Gender distribution and age of the sample, however, were not reported in that study. Also, the bilateral gnathodynamometer used was judged by Tortopidis, et al. ${ }^{30}$, as the device that has the greatest variability of repeated bite force measurements.

Caution is recommended when judging the present findings, because bruxism was diagnosed by questionnaire and physical examination and not by polysomnography.

Considering the sample utilized and the methodology used in this research, it was concluded that gender plays an important role on the maximum bite force, which, on the other hand, was not influenced by the presence of clinically detected bruxism.

\section{ACKNOWLEDGEMENTS}

Authors wish to thank all the participants for the cooperation and the National Council of Technological and Scientific Development (CNPq-Brazil) for the financial support.

\section{REFERENCES}

1- Pellizer EP, Muench A. Forças de mordida relacionadas a próteses removíveis inferiores [tese]. São Paulo (SP): Faculdade de Odontologia de São Paulo, Universidade de São Paulo; 1997.

2- Hatch JP, Shinkai RS, Sakai S, Rugh JD, Paunovich ED. Determinants of masticatory performance in dentate adults. Arch Oral Biol. 2001;46(7):641-8.

3- Rentes AM, Gavião MBD, Amaral JR. Bite force determination in children with primary dentition. J Oral Rehabil. 2002;19(12):117480 .

4- Paula LV. Estudo longitudinal da força de mordida de indivíduos dentados e edentados reabilitados com próteses convencionais e implanto-suportadas [tese]. São Paulo (SP): Faculdade de Odontologia de São Paulo, Universidade de São Paulo; 1998.

5- Glaros A. Incidence of diurnal and nocturnal bruxism. J Prosthet Dent. 1981;45(5):545-9.

6- Lavigne GJ, Montplaisir JY. Restless legs syndrome and sleep bruxism: prevalence and association among Canadians. Sleep. 1994;17(8):739-43.

7- Goulet JP, Lund JP, Montplaisir J, Lavigne G. Daily clenching, nocturnal bruxism, and stress and their association with TMD symptoms [abstract]. J Orofac Pain. 1993;7:120.

8- Waltimo A, Kononen M. A novel bite force recorder and maximal isometric bite force values for healthy young adults. Scand J Dent Res.1993;101(3):171-5.

9- Conti PCR, Ferreira PM, Pegoraro LF, Conti JV, Salvador MC. A cross-sectional study of prevalence and etiology of signs and symptoms of temporomandibular disorders in high school and university students. J Orofac Pain. 1996;10(3):254-62.

10- Lavigne GJ, Rompré PH, Montplaisir JY. Sleep bruxism: validity of clinical research diagnostic criteria in a controlled polysomnographic study. J Dent Res.1996;75(1):546-52.

11- Pullinger AG, Seligman DA, Gornbein JA. A multiple logistic regression analysis of the risk and relative odds of temporomandibular disorders as a function of common occlusal features. J Dent Res. 1993;72(6):968-79.

12- Kato T, Thie NM, Montplaisir JY, Lavigne GJ. Bruxism and orofacial movements during sleep. Dent Clin North Am. 2001;45(4):657-85.

13- Kato T, Rompre P, Montplaisir JY, Sessle BJ, Lavigne GJ. Sleep bruxism: an oromotor activity secondary to micro-arousal. J Dent Res. 2001;80(10):1940-4.

14- Molina OF, Santos Junior, Nelson SJ, Nowlin T. A clinical study of specific signs and symptoms of CMD in bruxers classified by the degree of severity. Cranio. 1999;17(4):268-79.

15- Linderholm $\mathrm{H}$, Wennstron A. Isometric bite force and its relation to general muscle force and body build. Acta Odontol Scand. 1970;28(5):679-89.

16- Linderholm $\mathrm{H}$, Lindqvist $\mathrm{B}$, Ringqvist $\mathrm{M}$, Wennstrom $\mathrm{A}$. Isometric bite force in children and its relation to body build and general muscle force. Acta Odontol Scand. 1971;29(5):563-8.

17- Landis JR, Koch GG. The measurement of observer agreement for categorical data. Biometrics. 1977;33(1):159-74. 
18- Gibbs CH, Mahan PE, Mauderli A, Lundeen HC, Walsh EK. Limits of human bite strength. J Prosthet Dent. 1986;56(2):226-9.

19- Helkimo E, Ingervall B. Bite force and functional state of the masticatory system in young men. Swed Dent J. 1978;2(5):167-75.

20- Helkimo E, Carlsson G E, Carmeli Y. Bite force and oral function in patients with disturbances of the masticatory system. J Oral Rehabil. 1975;2:397-406.

21- Killiaridis S, Johansson A, Haraldson T, Omar R, Carlsson GE. Craniofacial morphology, occlusal traits, and bite force in persons with advanced occlusal tooth wear. Am J Orthod Dentofac Orthop. 1995;107(3):286-91.

22- Lyons MF, Baxendale RH. A preliminary electromyographic study of bite force and jaw- closing muscle fatigue in human subjects with advanced tooth wear. J Oral Rehabil. 1990;17(4):311-8.

23- Raadsheer MC, van Eijden TM, van Ginkel FC, Prahl-Andersen B. Contribution of jaw muscle size and craniofacial morphology to human bite force magnitude. J Dent Res. 1999;78(1):31-42.

24- Fields H W, Proffit WR, Case JC, Vig KW. Variables affecting measurements of vertical occlusal force. J Dent Res. 1986;65(2):1358 .

25- Bakke M, Tuxen A, Vilmann P, Jensen BR, Vilmann A, Toft M. Ultrasound image of human masseter muscle related to bite force, electromyography, facial morphology, and occlusal factors. Scand J Dent Res. 1992;100(3):164-71.

26- Attanasio R. Nocturnal bruxism and its clinical management Dent Clin North Am. 1991;35(1):245-52.

27- Clark GT, Beemsterboer PL, Rugh JD. Nocturnal masseter muscle activity and the symptoms of masticatory dysfunction. J Oral Rehabil. 1981;8(3):279-86.

28- Nunes LMO. Associação entre bruxismo do sono e disfunção temporomandibular [tese]. Bauru (SP): Faculdade de Odontologia de Bauru, Universidade de São Paulo; 2003.

29- Dal Fabbro C. Estudo linear de um paciente com bruxismo através de análise eletromiográfica do músculo masseter, avaliação polissonográfica e psicológica [tese]. Bauru (SP): Faculdade de Odontologia de Bauru, Universidade de São Paulo; 1996.

30- Tortopidis D, Lyons MF, Baxendale RH, Gilmour WH. The variability of bite force measurement between sessions, in different positions within the dental arch. J Oral Rehabil. 1998;25(9):681-6. 